\title{
Aroma composition of Tempranillo grapes as affected by iron deficiency chlorosis and
}

\section{vine water status}

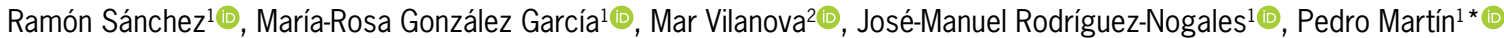

1Universidad de Valladolid - Departamento de Producción Vegetal y Recursos forestales, Av. de Madrid, 57 - 34004 Palencia - España.

${ }^{2}$ Consejo Superior de Investigaciones Científicas/Misión Biológica de Galicia, Apdo. de Correos, 28 - 38080 -

Pontevedra - España.

*Corresponding author <pmartinp@pvs.uva.es>

Edited by: Mohammad Bagher Hassanpouraghdam

Received April 18, 2019

Accepted August 09, 2019
ABSTRACT: Water deficit and iron nutritional deficiency (iron chlorosis) are frequent environmental stresses affecting grapevine production in the Mediterranean region. The objectives of this work were (i) to study the combined effects of both stresses on aromatic profile of Tempranillo grapes, occurring simultaneously in the vineyard, and (ii) to evaluate the viability of foliar chlorophyll content at veraison (Chl) to early assess aromatic quality potential of grapes in those conditions. Twenty non-irrigated vineyard subzones (10 m $\times 10 \mathrm{~m}$ each), affected and non-affected by iron chlorosis, were monitored in Ribera del Duero Appellation of Origin (NorthCentral Spain) during two consecutive seasons. Factorial ANOVA was performed to study the effects of predawn leaf water potential and $\mathrm{Chl}$ measured at veraison on the must composition parameters and, specifically, on the concentrations of free and bound aromatic compounds. Water deficit tended to increase color intensity and extractable anthocyanin content of the grapes, whereas the incidence of iron deficiency enhanced total phenolic compound content within subzones with better water status. More water or iron stressed subzones restricted $\mathrm{C}_{6}{ }^{-}$ alcohols contents than less stressed subzones. Without significant effects on vine vigor, yield or berry size, the incidence of iron chlorosis increased the concentrations of some specific terpenes, $\mathrm{C}_{13}$-norisoprenoids, volatile acids and volatile phenols. These results showed that low to moderate iron stress can have positive effects on grape aromatic quality, and demonstrated that $\mathrm{Chl}$ can be a useful tool in precision viticulture to map the aromatic potential within rainfed vineyards affected by iron chlorosis.

Keywords: Vitis vinifera L., chlorophyll, quality, volatile composition, water deficit

\section{Introduction}

Wine aroma is an essential marker of the product quality. Wine aroma is very complex and its perception is the result of a large number of volatile compounds (free and bound) present in very low concentrations. Free volatiles directly contribute to the varietal wine aroma, while bound compounds are found in grape juice as odorless conjugates, which can be turned into volatile forms through acid and enzymatic hydrolysis during winemaking, wine storage and ageing processes (López et al., 2004). Cultivar, and cultural practices are the most influential factors affecting the aromatic composition of grapes (Vilanova et al., 2007, 2017; González-Barreiro et al., 2015).

Iron deficiency chlorosis, in calcareous soils, and water deficit are common environmental stresses in the Mediterranean region, where they cause serious economic losses to grapevine production. Within nonirrigated vineyards, local variation in soil conditions, such as layer to be explored by the root system, texture, $\mathrm{pH}$ or active limestone content, can generate a wide variability in vine-to-vine water and/or iron status, affecting yield and grape composition (Martín et al., 2007; Li et al., 2017).

In different ways, water stress (Flexas et al., 2002) and iron chlorosis (Val et al., 1987; Bavaresco et al., 2006; Hailemichael et al., 2016) decline photosynthetic activity in grapevines, which depresses the synthesis and accumulation of substances in the fruits (Pirie and Mullins, 1980; Ojeda et al., 2002). Nevertheless, mild to moderate stress levels could have positive effects on grape quality, as the plants restrict vegetative growth, have less yield and smaller berries, concentrating constituents such as sugars and phenolic compounds (Balint and Reynolds, 2017; González et al., 2019).

A number of studies have investigated the effects of water stress or irrigation regimes on vines on grape volatile compounds (Song et al., 2012; Balint and Reynolds, 2014, 2017; Talaverano et al., 2017; Vilanova et al., 2019). However, there are currently no field studies on how iron deficiency affects aromatic fractions of grapes. The objectives of this work were (i) to study the combined effects of iron deficiency chlorosis incidence and the vineyard water status at veraison on aromatic (free and bound compounds) profile of Tempranillo grapes, and (ii) to evaluate the viability of foliar chlorophyll content, measured at veraison, to assess aromatic quality of grapes in rainfed vineyards affected by iron chlorosis.

\section{Materials and Methods}

\section{Study site description}

The study was conducted in the 2016 and 2017 seasons, on 20 non-irrigated vineyard subzones located in Pesquera de Duero (latitude 41 $38^{\prime} 34^{\prime \prime} \mathrm{N}$, longitude $4^{\circ} 09^{\prime} 27^{\prime \prime} \mathrm{W}$, Ribera del Duero Appellation of 
Origin area, North Central Spain), at $800 \mathrm{~m}$ above sea level. The soils in the study area are calcareous, very basic, and poor in organic matter, with high spatial variability in extractable potassium, phosphorus and magnesium contents (Zarco-Tejada et al., 2013). Soil texture ranged from medium to medium-weight. Concentrations of active carbonate (3-16 \%) and diethylenetriaminepentaacetic acid (DTPA) extractable iron (2.3-6.4 $\mathrm{mg} \mathrm{kg}^{-1}$ ) were highly heterogeneous within the area. Such soil properties, along with the presence of a lime sensitive rootstock as 110-Richter, led to different levels of iron deficiency chlorosis in the vineyards, from unaffected to moderately-affected.

The study area has a Mediterranean climate, with low temperatures in winter, and hot and dry summers. The monthly values of temperature and precipitation registered in the study years are shown in Table 1 . Mean annual temperatures were $11.9^{\circ} \mathrm{C}$ and $12.7^{\circ} \mathrm{C}$ in 2016 and 2017, respectively. In 2017 , late frosts $\left(-2.3{ }^{\circ} \mathrm{C}\right.$ in 28 Apr and $-0.7^{\circ} \mathrm{C}$ in 1 May) affected irregularly the subzones, restricting yield. The rainfall from 1 Apr to 30 Sept was $176 \mathrm{~mm}$ in 2016 and $142 \mathrm{~mm}$ in 2017. Without irrigation, these insufficient water supplies in soils, varying in texture and root explorable depth, ensured a broad variability of grapevine water status within the area.

The studied subzones $(10 \mathrm{~m} \times 10 \mathrm{~m}$ each) were located within 9.2 ha of vineyard, with 1.5 $\mathrm{km}$ of maximum distance between them. The sites were selected after a previous visual screening of the spatial variability on canopy size and color. Different topography, soil depth and soil physicochemical properties were chosen to ensure maximum variability in water and nutrient status across the sites, according to the purposes of the investigation. The vineyards correspond to Tempranillo cultivar, 15 to 20 years old, grafted on 110-Richter rootstock. Vines are spaced $3.0 \mathrm{~m}$ $\times 1.5 \mathrm{~m}$ (2222 plants $\left.\mathrm{ha}^{-1}\right)$ and trained in a vertical shoot positioning system. Eight spurs per vine, with two buds per spur, were retained during winter pruning.

\section{Field data collection}

Sixty petioles from fully expanded leaves were collected at veraison from each subzone for the mineral analysis. The sampling followed the recommendations of the OIV (1996). Nitrogen concentration was determined directly on the dried plant material by the Kjeldahl method. To determine the rest of nutrients, the samples were waved in an oven at $450^{\circ} \mathrm{C}$, extracting the minerals with $2 \mathrm{~N} \mathrm{HCl}$. In the extracts, $\mathrm{P}$ and $\mathrm{B}$ were analyzed spectrophotometrically, $\mathrm{Ca}, \mathrm{Mg}, \mathrm{Fe}, \mathrm{Mn}, \mathrm{Cu}$ and $\mathrm{Zn}$ by atomic absorption spectroscopy, and $\mathrm{K}$ by atomic emission spectroscopy. All results were expressed in percentage on dry matter basis.

Each season, data on foliar chlorophyll content (Chl) and predawn leaf water potential (LWP) were obtained in the study subzones at veraison stage, with $75 \%$ of colored berries (23-24 Aug 2016 and 9-10 Aug 2017). Chlorophyll content data were recorded by a portable colorimeter in 30 leaves taken at random in each subzone, always choosing the fourth or fifth leaf counting from the first sheet of the apex. Chlorophyll content per leaf area unit $\left(\mu \mathrm{g} \mathrm{cm}^{-2}\right)$ was calculated from colorimeter readings (R) by a regression line obtained previously for cv. Tempranillo:

$\mathrm{Chl}=6.0817 \cdot \mathrm{R}+7.6084$

Measurements of LWP were taken during $2 \mathrm{~h}$ before dawn (in equilibrium with soil water potential) with a Scholander pressure chamber. Values were recorded in six exposed leaves of different plants in each subzone.

Yield, 100-berry weight and winter pruning weight were determined, in 2016 and 2017 seasons, evaluating 21 plants in each subzone.

\section{Grape composition analysis}

Harvesting was performed in all subzones on the same day in each year, after the mean value of total soluble solid content of the must (TSS) in all study subzones had reached $22{ }^{\circ}$ Brix. At that moment, two samples of 100 berries from each subzone were collected. The must obtained from the first sample was used to determine TSS, total acidity (TA), yeast assimilable nitrogen concentration (YAN), $\mathrm{pH}$, potassium content, color intensity and hue, according to the European official methods of analysis (European Commission, 1990). The berries from the second sample were used to analyze total phenolic compound content (TPC), total

Table 1 - Monthly mean values of maximum $\left(T_{\max }\right)$, minimum $\left(T_{\min }\right)$ and average $\left(T_{\text {ave }}\right)$ temperature $\left({ }^{\circ} \mathrm{C}\right)$, and total precipitation $(P$, in mm), collected during the study years from Valbuena de Duero (Valladolid, Spain).

\begin{tabular}{|c|c|c|c|c|c|c|c|c|c|c|c|c|c|}
\hline Year & Variables & Jan & Feb & Mar & Apr & May & June & July & Aug & Sept & Oct & Nov & Dec \\
\hline \multirow{4}{*}{2016} & $T_{\max }$ & 9.2 & 9.8 & 11.7 & 14.6 & 19.7 & 27.5 & 32.0 & 31.5 & 27.2 & 21.4 & 12.2 & 9.5 \\
\hline & $\mathrm{T}_{\min }$ & 1.7 & 0.7 & -0.7 & 3.1 & 6.4 & 9.7 & 13.6 & 12.7 & 9.3 & 5.9 & 1.4 & -0.2 \\
\hline & $\mathrm{T}_{\text {ave }}$ & 5.3 & 5.0 & 5.2 & 8.6 & 12.9 & 18.9 & 22.8 & 22.3 & 18.2 & 13.1 & 6.4 & 3.7 \\
\hline & $\mathrm{P}$ & 136.4 & 56.8 & 40.3 & 87.1 & 45.3 & 6.8 & 27.9 & 0.4 & 8.8 & 38.6 & 61.2 & 14.0 \\
\hline \multirow{3}{*}{2017} & $\mathrm{~T}_{\max }$ & 9.2 & 12.7 & 16.5 & 21.1 & 24.2 & 30.7 & 30.7 & 30.3 & 25.5 & 24.1 & 14.1 & 9.2 \\
\hline & $\mathrm{T}_{\min }$ & -3.8 & 1.0 & 1.6 & 3.0 & 8.6 & 13.0 & 12.7 & 12.3 & 8.1 & 5.6 & -1.2 & -0.6 \\
\hline & $P$ & 14.8 & 35.5 & 19.7 & 4.2 & 50.2 & 16.9 & 52.7 & 18.9 & 0.0 & 11.6 & 17.9 & 30.3 \\
\hline
\end{tabular}


anthocyanin (TAN) and easily extractable anthocyanin (EA) contents, following the methodology described by Saint-Cricq et al. (1998). TAN and EA were expressed on the basis of berry fresh weight.

\section{Analysis of grape volatile compounds by GC-MS}

After harvest, $30 \mathrm{~kg}$ of grapes from each subzone were stored at $5{ }^{\circ} \mathrm{C}$ overnight before they were mechanically processed. Three hundred $\mathrm{mL}$ of must from de-stemmed/crushed grapes from each sample were collected and frozen immediately to $-20{ }^{\circ} \mathrm{C}$ until analysis.

To extract volatile compounds, the method described by Oliveira et al. (2008) was used with some modifications. Must samples were centrifuged $(\mathrm{RCF}=$ $9660,20 \mathrm{~min}, 4^{\circ} \mathrm{C}$ ) and filtered through a glass wool bed. We added $75 \mathrm{~mL}$ of juice, $3 \mu \mathrm{g}$ of 4-nonanol and passed it through a LiChrolut EN cartridge (Merck, $500 \mathrm{mg}, 40-120 \mu \mathrm{m})$. The resin was previously preconditioned with $10 \mathrm{~mL}$ of dichloromethane, $5 \mathrm{~mL}$ of methanol and $10 \mathrm{~mL}$ of aqueous alcoholic solution (10 $\%, \mathrm{v} / \mathrm{v})$. Free and bound volatile fractions were eluted successively with $5 \mathrm{~mL}$ of pentane-dichloromethane azeotrope and $7 \mathrm{~mL}$ of ethyl acetate, respectively. The pentane-dichloromethane elute was dried over anhydrous sodium sulphate and concentrated to $200 \mu \mathrm{L}$ by solvent evaporation with $\mathrm{N}_{2}$ prior to analysis. The ethyl acetate eluate was concentrated to dryness in a Multivapor ${ }^{\mathrm{TM}}$ from Buchi $\left(40{ }^{\circ} \mathrm{C}\right)$ and re-dissolved in $200 \mu \mathrm{L}$ of $0.1 \mathrm{M}$ citrate-phosphate buffer $(\mathrm{pH}=5.0)$. Fourteen milligrams of enzyme Rapidasa Revelation Aroma (Erbslöh) were added to the glycoside extract and the mixture was incubated at $40{ }^{\circ} \mathrm{C}$, for $12 \mathrm{~h}$. Released aglycons were extracted with pentane-dichloromethane azeotrope, after addition of $3 \mu \mathrm{g}$ of 4-nonanol as internal standard. The organic phase was then concentrated to $200 \mu \mathrm{L}$ with $\mathrm{N}_{2}$.

The gas chromatographic analysis of volatile compounds was performed using an Agilent GC $6890 \mathrm{~N}$ chromatograph coupled to mass spectrometer Agilent 5975C. A $1 \mu \mathrm{L}$ injection was made into a capillary column, coated with CP-Wax 52 CB $(50 \mathrm{~m} \times$ $0.25 \mathrm{~mm}$, i.d., $0.2 \mu \mathrm{m}$ film thickness, Chrompack). The temperature of the injector was programmed from $20^{\circ} \mathrm{C}$ to $250{ }^{\circ} \mathrm{C}$, at $180{ }^{\circ} \mathrm{C} \mathrm{min}^{-1}$. The oven temperature was kept at $40{ }^{\circ} \mathrm{C}$, for $5 \mathrm{~min}$, then programmed to rise from $40{ }^{\circ} \mathrm{C}$ to $250{ }^{\circ} \mathrm{C}$, at $3{ }^{\circ} \mathrm{C} \mathrm{min}{ }^{-1}$, then kept $20 \mathrm{~min}$ at $250{ }^{\circ} \mathrm{C}$ and finally programmed to go from $250{ }^{\circ} \mathrm{C}$ to $255^{\circ} \mathrm{C}$ at $1{ }^{\circ} \mathrm{C} \mathrm{min}{ }^{-1}$. The carrier gas was helium N60 at $103 \mathrm{kPa}$, which corresponds to a linear speed of $180 \mathrm{~cm}$ $\mathrm{s}^{-1}$ at $150{ }^{\circ} \mathrm{C}$. The detector was set to electronic impact mode $(70 \mathrm{eV})$, with an acquisition range from 29 to 360 $\mathrm{m} / \mathrm{z}$, and an acquisition rate of $610 \mathrm{~ms}$.

Identification was performed using the GC/MSD ChemStation Software (Agilent), by comparing mass spectra (Wiley and Nist libraries) and retention indices with those of pure standard compounds. Pure standard compounds were purchased from Sigma-Aldrich
(Darmstadt, Germany) with purity higher than $98 \%$. All compounds were quantified as 4-nonanol equivalents.

\section{Statistical analysis}

The factorial analysis of variance (ANOVA) and the Tukey test were performed to separate the effects of season, water status at veraison, and iron chlorosis incidence on vigor, yield and grape composition parameters, including free and bound aroma concentrations. For this, the subzones were previously classified into groups with high and low LWP, and with high and low Chl. The limit values for segmentation were the median of both explanatory variables in the subzones throughout the two years studied: $-0.737 \mathrm{MPa}$ and $99.9 \mu \mathrm{g} \mathrm{cm}^{-2}$, respectively.

The relationships between variables were studied using linear regression methods and Pearson correlation coefficients. All data analysis was performed with version 9.2 of SAS statistical software (Statistical Analysis System).

\section{Results and Discussion}

\section{Values of water potential and chlorophyll content}

The mean values of LWP in 2016 and 2017 (Table 2 ) indicated moderate to severe water deficit, according to ranges established from Van Leeuwen et al. (2009). The variability of water status between subzones at the beginning of ripening was clearly wider in 2017 than in 2016, registering a higher total precipitation in June, July and Aug (Table 1).

Both predawn and stem water potential measurements were useful to evaluate water status of Tempranillo grapevines (Santesteban et al., 2011). In this study, predawn values at veraison were considered as representative of water status of vineyard subzones. It is assumed that, in semiarid Mediterranean climates, the predawn potentials registered at veraison (at summer end, after a long dry period) in different vines within a vineyard could be correlated with the soil water availability throughout all the season and therefore

Table 2 - Minimum, maximum and coefficients of variation (CV) of foliar chlorophyll content (Chl) and predawn leaf water potential (LWP) measured at veraison.

\begin{tabular}{llcl}
\hline Year & Value & Chl & LWP \\
\hline \multirow{4}{*}{2016} & & $\mu g \mathrm{~cm}^{-2}$ & MPa \\
& Mean & $93.53 \mathrm{~b}$ & $-0.707 \mathrm{a}$ \\
& Min. & 32.93 & -0.491 \\
& Max. & 128.68 & -0.865 \\
& CV (\%) & 25.34 & 13.350 \\
\hline \multirow{4}{*}{2017} & Mean & $108.95 \mathrm{a}$ & $-0.708 \mathrm{a}$ \\
& Min. & 78.40 & -0.220 \\
& Max. & 160.44 & -0.900 \\
& CV (\%) & 21.02 & 23.970
\end{tabular}

In each column, means followed by the same letter are not significantly different $(p<0.05$, Tukey test). 
with their productive and qualitative potential. There were no rains in the month before the water potential measurements, nor abundant precipitations during fruit ripening period in the two years studied (Table 1), which might have limited the usefulness of LWP as indicator.

Mean values of $\mathrm{Chl}$ increased from 2016 to 2017 (Table 2). As Martín et al. (2008) previously demonstrated, Chl is strongly influenced by nutrient status in the study area, including the incidence of iron deficiency chlorosis. Positive correlations of $\mathrm{Chl}$ with petiole $\mathrm{N}(\mathrm{r}=0.39 ; p<0.05)$ and $\mathrm{K}$ contents $(\mathrm{r}=0.38$; $p<0.05)$, and negative with those $\mathrm{Mg}(\mathrm{r}=-0.55 ; p<$ $0.01)$ and $\mathrm{Mn}(\mathrm{r}=-0.33 ; p<0.05)$, were found when joined data of 2016 and 2017 were considered ( $n=40)$. Direct correlation with petiole $\mathrm{N}$ content demonstrate that Chl is part and parcel of vigor component of the grapevine. The correlation with the petiole $\mathrm{K}$ content might be related to its role in the absorption and transport of Fe (Tagliavini and Rombolà, 2001).

The petiole Fe content was not correlated with Chl, confirming that it is not a valid parameter to detect iron deficiency in grapevines (Bavaresco et al., 1999). When expressed on a dry weight basis, the Fe concentrations of control and chlorotic leaves are usually not significantly different because the deficiency reduces leaf area, which produces a concentration effect. Moreover, $\mathrm{Fe}$ may be immobilized somewhere in the chlorotic leaf in an unavailable form (Morales et al., 1998). On the other hand, $\mathrm{Mn}$ is antagonistic to $\mathrm{Fe}$, and might be accumulated in leaves from plants affected by iron deficiency (Millaleo et al., 2010). Mg and Fe might be also antagonistic, as proven in other species (Agarwala and Mehrotra, 1984).

According to previous studies carried out in the same area (Hailemichael et al., 2016; González et al., 2019), no consistent correlations were obtained between Chl and LWP in $2016(\mathrm{r}=0.04, p>0.05)$ and 2017 $(\mathrm{r}=0.12, p>0.05)$; therefore, both variables could be considered independent.

\section{Vigor, yield and fruit composition}

The results of factorial ANOVA (Table 3) show that the effects of season on vigor, yield, and grape composition parameters were almost always highly significant, evidencing a high variability of meteorological conditions between the study years. In the first season, the variability in water status at veraison was narrower than in the second (Table 2) and, consequently, the differences between subzones in terms of grape composition were smaller (Table 3).

With no damages caused by spring frosts and more water availability during the vegetative cycle, in 2016 , vineyard subzones registered higher yield $10.75 \mathrm{~kg}$ $\left.\mathrm{m}^{-2}\right)$, pruning weight $\left(0.26 \mathrm{~kg} \mathrm{~m}^{-2}\right)$ and 100-berry weight (177 g) than in $2017\left(0.44 \mathrm{~kg} \mathrm{~m}^{-2}, 0.15 \mathrm{~kg} \mathrm{~m}^{-2}\right.$ and $131 \mathrm{~g}$ respectively). Musts in 2016 had lower TSS than in 2017 (23.2 ${ }^{\circ}$ Brix versus $24.0^{\circ}$ Brix) and higher $\mathrm{pH}$ (3.7 versus 3.6), without significant differences in TA or YAN.

Vigor was affected by vineyard water status; thus, low LWP subzones registered pruning weights lower than high LWP subzones in $2017\left(0.11 \mathrm{~kg} \mathrm{~m}^{-2}\right.$ versus 0.19 $\left.\mathrm{kg} \mathrm{m}^{-2}, p<0.05\right)$. Neither Chl nor LWP significantly modified yield or berry weight (Table 3). These results do not agree with those of Tagliavini and Rombolà (2001) and Echeverría et al. (2017), probably because the iron deficiency was not intense enough in the study area. On the other hand, the lack of correlation between yield and vineyard water status at veraison in 2016 could be related to low variation coefficients of LWP in this season (Table 2). The non-significant relations in 2017 would be due to the incidence of spring frosts, which irregularly affected one and another subzone.

Iron chlorosis and water status modified differently grape composition parameters. Total acidity, YAN and TPC were mainly affected by Chl, whereas color intensity and EA were affected by LWP. The incidence of iron deficiency tended to advance fruit ripening; therefore, low Chl subzones reduced TA in relation to high Chl subzones in 2017 (3.9 $\mathrm{g} \mathrm{L}^{-1}$ versus $5.1 \mathrm{~g} \mathrm{~L}^{-1}$,

Table 3 - F-values of the factorial analysis of variance of vigor, yield and grape composition data obtained from vineyard subzones with high and low predawn leaf water potential (LWP) and high and low foliar chlorophyll content at veraison (Chl), in 2016 and 2017.

\begin{tabular}{|c|c|c|c|c|c|}
\hline Variables & Model & Year & $\mathrm{Chl}$ & LWP & $\mathrm{LWP}^{\star} \mathrm{Chl}$ \\
\hline Pruning weight & $10.19^{* * *}$ & $26.03^{* * *}$ & 3.23 & $4.61^{*}$ & 4.07 \\
\hline Yield & $6.95^{* * *}$ & $25.68^{* * *}$ & 0.41 & 0.00 & 3.17 \\
\hline 100 Berry weight & $19.39^{* * *}$ & $67.78^{* * *}$ & 0.81 & 3.42 & 0.17 \\
\hline Yeast assimilable nitrogen & 1.96 & 1.11 & $4.33^{*}$ & 1.44 & 0.91 \\
\hline Total soluble solids & $3.75^{*}$ & $12.58^{* *}$ & 0.03 & 0.03 & 3.48 \\
\hline $\mathrm{pH}$ & $11.53^{* * *}$ & $43.68^{* * *}$ & 0.01 & 0.50 & 0.36 \\
\hline Color intensity & $8.79 * * *$ & $21.58^{* * *}$ & 0.00 & $8.12^{* *}$ & 2.27 \\
\hline Hue & $14.26^{* * *}$ & $46.93^{\star \star *}$ & 0.09 & 2.61 & 1.10 \\
\hline Potassium & $6.65^{* * *}$ & $21.95^{\star \star \star}$ & 2.02 & 0.21 & 0.65 \\
\hline Total phenolic compounds & $23.35^{* * *}$ & $65.49^{* * *}$ & $7.74^{*}$ & 0.14 & $6.84^{*}$ \\
\hline Easily extractable anthocyanins & $7.60 * * *$ & $17.88^{* * *}$ & 2.06 & $5.76^{*}$ & 0.38 \\
\hline Total anthocyanins & $4.93^{\star *}$ & $16.01^{* * *}$ & 0.25 & 2.16 & 0.25 \\
\hline
\end{tabular}


$p<0.05)$, reaching better maturity indexes. Regardless of study year, low Chl subzones had less YAN than high Chl subzones (158 $\mathrm{mg} \mathrm{L}^{-1}$ versus $190 \mathrm{mg} \mathrm{L}^{-1}, p<0.05$ ). Iron deficiency restricted nitrogen availability to vines, as proven by the positive correlation between $\mathrm{Chl}$ and petiole $\mathrm{N}$ content referred above.

Increases in TPC were associated to the incidence of iron deficiency, according to Bavaresco et al. (2005) and González et al. (2019). However, due to LWP $\times$ Chl interaction (Table 3), differences between low and high Chl values were detected $(p<0.05)$ only in subzones with better water status at veraison $\left(1529 \mathrm{mg} \mathrm{kg}^{-1}\right.$ versus $1180 \mathrm{mg} \mathrm{kg}^{-1}$ in 2016, $940 \mathrm{mg} \mathrm{kg}^{-1}$ versus $780 \mathrm{mg} \mathrm{kg}^{-1}$ in 2017). Since the effects of iron chlorosis on vine vigor were not significant (Table 3), the increase in TPC might be more attributed to a direct effect on biosynthesis of polyphenols in grapes than to changes in the cluster microclimate. Bavaresco et al. (2005) suggested that, as iron is a constituent of enzymes involved in lignin

Table 4 - F-values of factorial analysis of variance of data on free volatile compound concentrations of musts obtained from vineyard subzones with high and low predawn leaf water potential (LWP), and with high and low foliar chlorophyll content at veraison (Chl), in 2016 and 2017.

\begin{tabular}{|c|c|c|c|c|c|}
\hline Group / compound & Model & Year & $\mathrm{Chl}$ & LWP & $\mathrm{Chl}^{*} \mathrm{LWP}$ \\
\hline \multicolumn{6}{|l|}{ Alcohols } \\
\hline 1-Butanol & $5.05^{* *}$ & $16.6^{* *}$ & 1.05 & 0.00 & 0.95 \\
\hline$(2+3)$-Methyl-1-butanol & $7.16^{\star *}$ & $21.6^{\star * *}$ & 1.24 & 2.83 & 2.21 \\
\hline 4-Methyl-1-pentanola & 0.60 & NA & 0.16 & 0.91 & 0.56 \\
\hline 3-Methyl-1-pentanol & $8.31^{* * *}$ & $30.96^{* * *}$ & * 0.34 & 0.03 & 0.10 \\
\hline Benzyl alcohol & 1.48 & 1.56 & 0.94 & 1.79 & 0.81 \\
\hline 2-Phenylethanol & 1.65 & 3.25 & 1.29 & 1.33 & 0.08 \\
\hline $\begin{array}{l}\text { 3-Methyl-3-buten-1-ol+1- } \\
\text { pentanol }\end{array}$ & 0.57 & NA & 0.03 & 0.27 & 1.00 \\
\hline 1-Octanolb & 2.65 & NA & 3.28 & 1.11 & 0.89 \\
\hline Total & $30.17^{* * *}$ & $115.89^{* * *}$ & * 0.13 & 0.29 & 2.52 \\
\hline \multicolumn{6}{|l|}{ C-Alcohols } \\
\hline 1-Hexanol & $3.89^{*}$ & 1.64 & $5.70^{*}$ & 1.07 & 3.16 \\
\hline (E)-3-Hexen-1-ol & 36.20 ** * & $141.87^{* * *}$ & * 3.31 & 0.06 & $4.82^{*}$ \\
\hline (Z)-2-Hexen-1-ol & $62.06^{* * *}$ & $243.39 * * *$ & * 2.66 & 0.22 & 2.41 \\
\hline (Z)-3-Hexen-1-olb & 2.37 & NA & 2.32 & 0.04 & 4.06 \\
\hline (E)-2-Hexen-1-ol ${ }^{b}$ & 1.68 & NA & 0.85 & 1.72 & 0.51 \\
\hline Total & $4.42^{* *}$ & 1.6 & $5.38^{*}$ & 1.50 & $4.84^{*}$ \\
\hline \multicolumn{6}{|l|}{ Aldehydes } \\
\hline Phenylethanola & 0.36 & & 0.07 & 0.40 & 0.48 \\
\hline Hexanal & $11.54^{* \star *}$ & $43.38^{* * *}$ & * 0.08 & 0.41 & 1.29 \\
\hline (E)-2-Hexenal & 1.23 & 0.22 & 2.72 & 0.01 & 1.72 \\
\hline Benzaldehyde ${ }^{b}$ & 1.25 & NA & 0.95 & 0.48 & 1.17 \\
\hline Total & 2.55 & 3.39 & 2.36 & 1.71 & 1.08 \\
\hline \multicolumn{6}{|l|}{ Terpenes } \\
\hline Diendiol (II) & 0.59 & 1.46 & 0.03 & 0.89 & 0.24 \\
\hline Terpinen-4-ol ${ }^{b}$ & 1.76 & NA & 2.75 & 0.00 & 2.39 \\
\hline$\alpha$-terpineol $^{b}$ & 1.28 & NA & 2.04 & 0.03 & 1.93 \\
\hline $\begin{array}{l}\text { Trans-Pyran-linalool oxide } \\
(\text { LOP) }\end{array}$ & 1.13 & NA & 0.36 & 0.90 & 0.91 \\
\hline
\end{tabular}

Continue... synthesis, iron deficiency may switch the shikimate pathway towards other phenolics.

The subzones with low LWP showed higher potassium content than those with high LWP in 2017 (1004 mg kg-1 versus $778 \mathrm{mg} \mathrm{kg}^{-1}, p<0.05$ ), probably because vine water stress triggered a greater translocation of $\mathrm{K}^{+}$cations from leaves to berries (Boulton, 1980). In this season, low versus high LWP subzones increased EA (1003 versus $\left.778 \mathrm{mg} \mathrm{kg}^{-1}, p<0.05\right)$ and must color intensity (3.11 versus $1.89, p<0.05)$. This rise of the coloring matter concentration might be a consequence of both an increase in fruit exposure to sunlight (lower canopy density) and a direct stimulation of anthocyanin biosynthesis enzymes in more water stressed plants (Romero et al., 2010).

\section{Free and bound aroma compounds}

We identified and quantified 43 free and 45 bound aromatic compounds in must samples (Tables 4 and 5).

Table 4 - Continuation.

\begin{tabular}{|c|c|c|c|c|c|}
\hline$\beta$-Citronellol ${ }^{b}$ & 0.26 & NA & 0.01 & 0.26 & 0.25 \\
\hline Nerolb $^{b}$ & 3.20 & NA & $8.07^{*}$ & 3.22 & 2.56 \\
\hline Geraniol $^{b}$ & 0.38 & NA & 0.10 & 0.35 & 0.27 \\
\hline Diendiol $(I)^{b}$ & 0.46 & NA & 0.11 & 0.20 & 0.68 \\
\hline Total & $35.41^{* * *}$ & $137.09^{* * *}$ & 0.09 & 1.18 & 0.03 \\
\hline $\begin{array}{l}\text { Acetoin (carbonyl } \\
\text { compound) }\end{array}$ & 0.40 & NA & 0.22 & 0.07 & 0.75 \\
\hline \multicolumn{6}{|l|}{ Volatile acids } \\
\hline Hexanoic acid & 2.66 & $7.22^{*}$ & 0.45 & 0.80 & 0.62 \\
\hline Hexadecanoic acid & 1.61 & 3.58 & 0.94 & 0.01 & 2.48 \\
\hline Geranic acidb & 0.62 & NA & 1.28 & 0.18 & 0.28 \\
\hline Total & $6.09^{* *}$ & $23.78^{* * *}$ & 0.73 & 0.14 & 1.13 \\
\hline \multicolumn{6}{|l|}{$\mathrm{C}_{13}$-Norisoprenoids } \\
\hline 3-hydroxy- $\beta$-damascone ${ }^{a}$ & 1.57 & NA & 0.48 & 1.72 & 1.95 \\
\hline 3-0xo-7,8-dihydro- $\alpha$-ionol & 0.32 & 0.04 & 0.33 & 0.60 & 0.02 \\
\hline 3-0xo-a-ionol ${ }^{b}$ & 0.63 & NA & 1.47 & 0.41 & 0.11 \\
\hline 4-0xo-7,8-dihydro- $\beta$-ionol ${ }^{b}$ & 0.45 & NA & 0.22 & 0.09 & 0.86 \\
\hline Total & $3.99^{* *}$ & $15.27^{* *}$ & 0.07 & 0.68 & 0.01 \\
\hline \multicolumn{6}{|l|}{ Volatile phenols } \\
\hline Guaiacol & $18.93^{* * *}$ & $70.08^{* * *}$ & 0.16 & 0.84 & 0.36 \\
\hline Vanillin & 2.45 & $9.42^{* *}$ & 0.82 & 0.69 & 0.00 \\
\hline Acetovanillone & $3.13^{*}$ & $12.29^{* *}$ & 0.12 & 0.11 & 0.37 \\
\hline 4-Ethylphenol ${ }^{b}$ & 0.47 & NA & 0.34 & 0.32 & 0.22 \\
\hline 4-Vinylphenol ${ }^{\mathrm{b}}$ & 0.14 & NA & 0.00 & 0.18 & 0.12 \\
\hline Total & $14.93^{* * *}$ & $57.26^{\text {** * }}$ & 0.01 & 0.72 & 0.03 \\
\hline \multicolumn{6}{|l|}{ Acetates } \\
\hline Isoamyl acetate & $56.43^{* * *}$ & 217.50 *** & 0.05 & 1.35 & 0.14 \\
\hline 2-Methyl-1-butyl acetate ${ }^{b}$ & 0.80 & NA & 1.11 & 0.01 & 0.87 \\
\hline Total & $60.97^{* * *}$ & $235.12^{* * *}$ & 0.08 & 1.41 & 0.17 \\
\hline \multicolumn{6}{|l|}{ Ethyl esters } \\
\hline Ethyl hexanoate ${ }^{b}$ & 1.55 & NA & 2.37 & 0.03 & 1.72 \\
\hline Ethyl octanoate ${ }^{\mathrm{b}}$ & 1.34 & NA & 2.08 & 0.00 & 1.74 \\
\hline Total $^{\mathrm{b}}$ & 1.50 & NA & 2.31 & 0.01 & 1.79 \\
\hline$\gamma$-Butyrolactone (lactone) & 1.18 & 2.43 & 0.22 & 1.52 & 0.00 \\
\hline Total free aromas & $3.97^{* *}$ & $8.55^{* *}$ & 0.24 & 0.94 & 4.11 \\
\hline
\end{tabular}


Table 5 - F-values of the factorial analysis of variance of data on bound volatile compound concentrations of the musts obtained from vineyard subzones with high and low predawn leaf water potential (LWP), and with high and low foliar chlorophyll content at veraison (Chl), in 2016 and 2017.

\begin{tabular}{|c|c|c|c|c|c|}
\hline Group /compound & Model & Year & $\mathrm{Chl}$ & LWP & $\mathrm{Chl}^{*} \mathrm{LWP}$ \\
\hline \multicolumn{6}{|l|}{ Alcohols } \\
\hline 3-Methyl-1-pentanol & 2.82 & $8.29^{* *}$ & 0.09 & 0.63 & 2.30 \\
\hline 1-Octanola & 1.13 & NA & 0.07 & 2.55 & 0.22 \\
\hline Benzyl alcohol & $10.06^{* * *}$ & * $32.90^{* * *}$ & 3.40 & 0.00 & 1.28 \\
\hline 2-Phenylethanol & $16.94^{* * *}$ & * $61.05^{* * *}$ & 2.20 & 0.11 & 0.76 \\
\hline 1-Butanol ${ }^{b}$ & 0.35 & NA & 0.82 & 0.15 & 0.06 \\
\hline$(2+3)-$ Methyl-1-butanol & 1.80 & NA & $4.54^{*}$ & 1.38 & 1.98 \\
\hline $\begin{array}{l}\text { 3-Methyl-3-buten-1-ol+1- } \\
\text { pentanol }\end{array}$ & 0.52 & NA & 0.37 & 0.44 & 0.09 \\
\hline 4-Methyl-1-pentanol ${ }^{b}$ & 0.86 & NA & 2.30 & 0.20 & 0.60 \\
\hline Dodecanol $^{\mathrm{b}}$ & 1.64 & NA & 0.00 & 0.06 & 4.59 \\
\hline Total & $4.23^{\star *}$ & $12.62^{* *}$ & 1.18 & 0.01 & 2.89 \\
\hline \multicolumn{6}{|l|}{$\mathrm{C}_{6}$-Alcohols } \\
\hline 1-Hexanol & $4.37^{* *}$ & $16.79^{* *}$ & 0.07 & 0.16 & 0.25 \\
\hline (E)-3-Hexen-1-ola & 0.51 & NA & 0.02 & 0.62 & 0.62 \\
\hline (Z)-2-Hexen-1-ol & 2.13 & $6.81^{*}$ & 0.31 & 0.91 & 0.12 \\
\hline (E)-2-Hexen-1-olb & 1.55 & NA & 0.22 & 3.31 & 2.04 \\
\hline Total & $5.07^{* *}$ & $18.94^{* * *}$ & 0.15 & 0.75 & 0.33 \\
\hline \multicolumn{6}{|l|}{ Aldehydes } \\
\hline (E)-2-Hexenal & $8.12^{* \star *}$ & * $27.85^{* * *}$ & 0.97 & 1.86 & 0.91 \\
\hline Hexanal ${ }^{b}$ & 1.16 & NA & 2.85 & 0.02 & 0.01 \\
\hline Total & $5.05^{* *}$ & $15.62^{* *}$ & 1.23 & 0.07 & 1.85 \\
\hline \multicolumn{6}{|l|}{ Terpenes } \\
\hline$\beta$-Citronellola & 1.20 & NA & 0.07 & 1.64 & 1.27 \\
\hline Diendiol (I) & 0.81 & NA & 1.97 & 0.09 & 0.14 \\
\hline (E)-8-hydroxylinaloola & 0.56 & NA & 0.09 & 0.33 & 1.52 \\
\hline Geraniol $^{b}$ & 2.70 & NA & $7.25^{*}$ & 4.05 & 0.37 \\
\hline Total & $8.99^{* * *}$ & * $31.27^{* * *}$ & 0.69 & 2.37 & 1.38 \\
\hline \multicolumn{6}{|l|}{ Volatile acids } \\
\hline Hexanoic acida & 0.60 & NA & 0.32 & 0.66 & 0.48 \\
\hline (E)-2-Hexanoic acid & 0.90 & 1.86 & 0.57 & 1.80 & 0.19 \\
\hline Octanoic acida & 0.42 & NA & 0.46 & 0.77 & 0.09 \\
\hline Hexadecanoic acid & $4.03^{* *}$ & $7.45^{* *}$ & $5.13^{*}$ & 0.39 & 0.86 \\
\hline $\begin{array}{l}\text { (2+3)-Methylbutanoic } \\
\text { acids }^{b}\end{array}$ & $3.82^{*}$ & NA & $6.69^{*}$ & 3.40 & 1.49 \\
\hline Total & $5.58^{* *}$ & $16.13^{* *}$ & 2.68 & 0.00 & 0.47 \\
\hline \multicolumn{6}{|l|}{$\mathrm{C}_{13}$-Norisoprenoids } \\
\hline 3-hydroxy- $\beta$-damascone ${ }^{a}$ & 0.75 & NA & 1.52 & 0.23 & 0.36 \\
\hline 3-0xo- $\alpha$-ionol & 5.13 & $11.52^{* *}$ & $6.16^{*}$ & 0.02 & 0.31 \\
\hline $\begin{array}{l}\text { 3-Hydroxy-7,8-dihydro- } \\
\beta \text {-ionol }\end{array}$ & 2.49 & $6.11^{*}$ & 0.37 & 2.23 & 0.01 \\
\hline 4-0xo-7,8-dihydro- $\beta$-ionol & 1.94 & 0.14 & $6.66^{*}$ & 0.07 & 0.35 \\
\hline 3-0xo-7,8-dihydro- $\alpha$-ionol & 1.48 & 2.05 & 1.25 & 3.35 & 0.66 \\
\hline $\begin{array}{l}\text { 3-Hydroxy-7,8-dihydro- } \\
\beta \text {-ionol }\end{array}$ & 1.73 & NA & $5.02^{*}$ & 1.84 & 0.52 \\
\hline Total & $4.01^{* *}$ & $13.4^{* *}$ & 0.41 & 0.44 & 0.12 \\
\hline \multicolumn{6}{|l|}{ Volatile phenols } \\
\hline Guaiacol & 1.02 & 0.27 & 1.21 & 0.43 & 1.40 \\
\hline 4-ethyl phenola & 0.98 & NA & 0.10 & 2.92 & 0.13 \\
\hline 4-Vinylguaiacol & $4.39^{* *}$ & $15.12^{* *}$ & 0.50 & 0.17 & 2.38 \\
\hline 4-Vinylphenol & $5.49^{* *}$ & $20.89^{* * *}$ & 0.00 & 0.61 & 2.13 \\
\hline Vanillin & 2.14 & 0.84 & 3.44 & 3.68 & 1.13 \\
\hline
\end{tabular}

Table 5 - Continuation.

\begin{tabular}{|c|c|c|c|c|c|}
\hline Eugenol $^{\mathrm{b}}$ & $8.96^{* *}$ & NA & $26.19 * * *$ & 2.57 & 1.98 \\
\hline Methyl vanillate ${ }^{b}$ & 1.44 & NA & 2.38 & 3.41 & 0.00 \\
\hline Acetovanillone $^{b}$ & 2.20 & NA & $4.62^{*}$ & 2.11 & 0.42 \\
\hline 3,4-Dimethoxyphenol ${ }^{\mathrm{b}}$ & 2.71 & NA & $6.12^{*}$ & 0.02 & 0.00 \\
\hline Total & 1.81 & 3.88 & 2.24 & 0.40 & 0.13 \\
\hline \multicolumn{6}{|l|}{ Acetates } \\
\hline Isoamyl acetate & $14.14^{* * *}$ & $53.41^{* * *}$ & 0.87 & 0.17 & 0.77 \\
\hline Hexyl acetate & $7.55^{* *}$ & $29.58^{* * *}$ & 0.01 & 0.18 & 0.97 \\
\hline 2-Phenylethyl acetate ${ }^{b}$ & 0.19 & NA & 0.49 & 0.02 & 0.00 \\
\hline Total & $11.11^{* * *}$ & $41.12^{* \star *}$ & 0.82 & 0.11 & 1.08 \\
\hline$\gamma$-butyrolactone (lactone) & $4.07^{\star \star}$ & $14.58^{* *}$ & 0.33 & 3.34 & 0.02 \\
\hline \multicolumn{6}{|l|}{ Ethyl esters } \\
\hline Ethyl hexanoate ${ }^{b}$ & 0.38 & NA & 1.02 & 0.21 & 0.01 \\
\hline Ethyl octanoate ${ }^{b}$ & 0.36 & NA & 0.87 & 0.00 & 0.04 \\
\hline Total $^{b}$ & 0.35 & NA & 0.98 & 0.07 & 0.00 \\
\hline Total bound aromas & $7.61^{* *}$ & $24.48^{* * *}$ & 2.95 & 0.05 & 0.18 \\
\hline Total aromas & 1.54 & 2.42 & 0.91 & 0.15 & 2.53 \\
\hline
\end{tabular}

* Significant $p<0.05 ;{ }^{* *}$ Significant $p<0.01 ;{ }^{* *}$ S Significant $p<0.001$. aetected only in 2016; betected only in 2017. NA = not applicable.

Among free aromas, alcohols and terpenes constituted the most abundant groups in number of compounds determined. Among glycosylated bound compounds, alcohols and volatile phenols were the most abundant. The number of free terpenes detected increased from 1 , in 2016, to 8, in 2017, while bound terpenes varied from 3 to 1 . Acetoin and ethyl esters (free and bound) were detected only in 2017.

The concentrations of total free compounds and most groups quantified in the two seasons showed interannual differences (Table 4). These results are in agreement with the analysis of volatile components from different white and red grape varieties /Chardonnay, Sauvignon blanc, Semillon, Merlot, Syrah and Melon blanc) that showed a strong year-to-year variation (Bureau et al., 2000; Robinson et al., 2014). Total free aroma concentrations were higher in $2017\left(1160 \mu \mathrm{g} \mathrm{L}^{-1}\right)$ than in $2016\left(961 \mu \mathrm{g} \mathrm{L}^{-1}\right)$, mainly due to differences on isoamyl acetate concentrations $\left(237 \mu \mathrm{g} \mathrm{L} \mathrm{L}^{-1}\right.$ versus $21 \mu \mathrm{g}$ $\mathrm{L}^{-1}$, respectively). When bound aroma compounds were considered (Table 5), total values in 2016 were higher

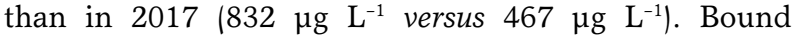
alcohols, $\mathrm{C}_{6}$-alcohols, aldehydes, terpenes, volatile acids, $\mathrm{C}_{13}$-norisoprenoids, volatile phenols and lactones decreased from 2016 to 2017, while acetates increased. In the groups, maximum differences were observed for (E)-2-hexenal $\left(11 \mu \mathrm{g} \mathrm{L}^{-1}\right.$ versus $\left.3 \mu \mathrm{g} \mathrm{L}^{-1}\right)$, total bound terpenes $\left(73 \mu \mathrm{g} \mathrm{L}^{-1}\right.$ versus $\left.2 \mu \mathrm{g} \mathrm{L}^{-1}\right)$ and $\gamma$-butyrolactone $\left(57 \mu \mathrm{g} \mathrm{L}^{-1}\right.$ versus $\left.3 \mu \mathrm{g} \mathrm{L}^{-1}\right)$. Finally, total concentrations of (free + bound) aroma compounds quantified in 2016 and 2017 were not different $(p>0.05)$.

The ANOVAs in Tables 4 and 5 show that vineyard water status at veraison did not modify the volatile profile of the must. Nevertheless, in 2016, LWP was positively correlated with free benzyl alcohol concentration $(\mathrm{r}$ $=0.46, p<0.05)$ and negatively correlated to total 
aldehydes that were determined $(\mathrm{r}=-0.48, p<0.05)$, including free phenylethanol $(\mathrm{r}=-0.49 ; p<0.05)$ and bound 4-ethyl phenol $(\mathrm{r}=-0.51, p<0.05)$ concentrations. In 2017, LWP correlated with free (Z)-3-hexen-1-ol ( $\mathrm{r}=$ $0.53 p<0.05)$, total bound $\mathrm{C}_{6}$-alcohols $(\mathrm{r}=0.58, p<$ 0.01 ) and, within this family, with (Z)-2-hexen-1-ol and (E)-2-hexen-1-ol concentrations. Moreover, LWP was correlated to bound 1-hexanol $(\mathrm{r}=0.45, p<0.01)$ and $(2+3)$-methylbutanoic acid concentration $(\mathrm{r}=0.47, p<$ $0.05)$.

$\mathrm{C}_{6}$-Alcohols are responsible, to some extent, for the green herbaceous and vegetable aromas in wines, which is a negative quality attribute (González-Barreiro et al., 2015). The correlations between LWP and $\mathrm{C}_{6}$-alcohols are in agreement with sensory evaluation of Baconoir (Balint and Reynolds, 2017), Pinot noir (Ledderhof et al., 2014) and Cabernet sauvignon (Chapman et al., 2005) wines, suggesting that vines with higher water status were associated to more herbaceous and vegetal wines. Several studies have documented that irrigation regimes based on different reference evapotranspiration (ETo) levels modified the vegetal and herbaceous character of wines. Balint and Reynolds (2017) reported that moderate irrigation (50\% $\mathrm{ET}_{\mathrm{o}}$ ) combined with an early start (start irrigation at fruit set) increased the sensory attribute of fresh grass in comparison to non-irrigated control in Chardonnay wines. Gamero et al. (2014) found that Tempranillo wines from full irrigation (100\% $\mathrm{ET}_{\mathrm{o}}$ ) vines versus deficit irrigation (25\% $\mathrm{ET}_{\mathrm{o}}$ ) vines showed higher herbaceous aroma. Deficit irrigation (25\% ET) was also associated to reductions in vegetal aroma in Syrah wines (Reynolds et al., 2012). Studies performed by Talaverano et al. (2017) showed the water status in Tempranillo vines affected total alcohols, $\mathrm{C}_{6}$-compounds and phenol volatiles families, producing the highest concentrations at the lower level of water availability. However, there was no effect on ethyl esters, acetates, volatile fatty acids, and lactones. Recent studies on Verdejo wines reported that concentrations of volatile compounds were increased in non-irrigated vines versus different deficit irrigation regimes (25\% and $50 \% \mathrm{ET}_{\mathrm{o}}$ ) (Vilanova et al., 2019).

As Table 6 presents, vines with low $\mathrm{Chl}$ produced in 2016 musts with lower content of free total $\mathrm{C}_{6}$ alcohols than those of high Chl, particularly 1-hexanol, although the LWP $\times$ Chl interaction (Table 4) caused significant differences between means only within high LWP study subzones (184 $\mu \mathrm{g} \mathrm{L}^{-1}$ versus $\left.110 \mu \mathrm{g} \mathrm{L} \mathrm{L}^{-1}\right)$. The concentrations of $\mathrm{C}_{6}$-alcohols in grapes decrease during ripening (Salinas et al., 2004). The metabolism of these compounds is initiated by the action of lipoxygenase enzymes on polyunsaturated fatty acids, which catalyze the formation of the corresponding hydroperoxides. The presence of an atom of iron as cofactor at the active site of lipoxygenases is essential for their catalytic action (Podolyan et al., 2010). The hydroperoxides obtained may be transformed into $\mathrm{C}_{6}$-aldehydes by hydroperoxidelyase enzymes. Then, some of these can
Table 6 - Significant mean separations of volatile compound concentrations in the must from vineyard subzones with different foliar chlorophyll content (Chl) at veraison.

\begin{tabular}{|c|c|c|c|}
\hline \multirow{2}{*}{ Year } & \multirow{2}{*}{ Compound / groups } & \multicolumn{2}{|c|}{ Concentrations } \\
\hline & & Low Chl & High Chl \\
\hline & & \multicolumn{2}{|c|}{$\longrightarrow \mu \mathrm{g} \mathrm{L}^{-1} \longrightarrow$} \\
\hline \multirow{6}{*}{2016} & \multicolumn{3}{|l|}{ Free aromas } \\
\hline & Total $\mathrm{C}_{6}$-alcohols & $285.62 \mathrm{~b}$ & $376.05 \mathrm{a}$ \\
\hline & 1-Hexanol ( $\mathrm{C}_{6}$-alcohol) & $125.41 b$ & $172.95 \mathrm{a}$ \\
\hline & \multicolumn{3}{|l|}{ Bound aromas } \\
\hline & 3-0xo- $\alpha$-ionol ( $\mathrm{C}_{13}$-norisoprenoid) & $39.27 \mathrm{a}$ & $16.79 \mathrm{~b}$ \\
\hline & 4-0xo-7,8-dihydro- $\beta$-ionol ( $\mathrm{C}_{13}$-norisoprenoid) & $14.63 \mathrm{a}$ & $2.51 \mathrm{~b}$ \\
\hline \multicolumn{4}{|c|}{ Free aromas } \\
\hline \multirow{10}{*}{2017} & 1-Octanol (Alcohol) & $0.97 \mathrm{a}$ & $0.72 b$ \\
\hline & Nerol (Terpene) & $3.54 \mathrm{a}$ & $3.09 \mathrm{~b}$ \\
\hline & Bound aromas & & \\
\hline & Total volatile acids & $102.09 \mathrm{a}$ & $75.19 b$ \\
\hline & Hexadecanoic acid (volatile acid) & $86.62 \mathrm{a}$ & $63.05 b$ \\
\hline & (2+3)-Methylbutanoic acid (volatile acid) & $0.96 a$ & $0.68 \mathrm{~b}$ \\
\hline & 3-0xo- $\alpha$-ionol ( $\mathrm{C}_{13}$-norisoprenoid) & $12.37 \mathrm{a}$ & $7.81 \mathrm{~b}$ \\
\hline & $\begin{array}{l}\text { 3-Hydroxy-7,8-dihydro- } \beta \text {-ionol }\left(\mathrm{C}_{13}{ }^{-}\right. \\
\text {norisoprenoid) }\end{array}$ & $7.37 \mathrm{a}$ & $4.78 b$ \\
\hline & Eugenol (volatile phenol) & $2.90 \mathrm{a}$ & $2.04 \mathrm{~b}$ \\
\hline & 3,4-Dimethoxyphenol (volatile phenol) & $9.14 \mathrm{a}$ & $3.50 \mathrm{~b}$ \\
\hline
\end{tabular}

In each row, means followed by the same letter are not significantly different $(p<0.05$, Tukey test).

be reduced to $\mathrm{C}_{6}$-alcohols by alcohol dehydrogenases in grapes (Mozzon et al., 2016). Recent studies investigated the effect of iron deficiency on the genomewide transcriptional characterization of grapevine and confirmed that the expression of lipoxygenase gen was down-regulated in iron stressed plants compared to the control ones (Vannozzi et al., 2017). Therefore, the lower concentration of $\mathrm{C}_{6}$-alcohols observed in subzones with low $\mathrm{Chl}$ could be explained by a decline in the activity of these iron-containing lipoxygenases.

In 2017, must from subzones with low Chl had higher content of 1-octanol, nerol, total bound volatile acids, eugenol and 3,4-dimethoxyphenol than the others. In general, subzones affected by iron chlorosis increased the amounts of some bound $\mathrm{C}_{13}$-norisoprenoids. 3-Oxo$\alpha$-ionol, a spice tasting compound of grapes, was more abundant in must from more chlorotic subzones in the two seasons. These results agree with those of Coelho et al. (2009), who reported that concentrations of monoterpenoids, sesquiterpenoids, and $\mathrm{C}_{13}$ norisoprenoids in sparkling wines from vines cultivated in calcareous soils (where iron availability might be limited) were higher than in those of clay and sandy origin.

$\mathrm{C}_{13}$-Norisoprenoids are a diverse group of volatile compounds derived from grape carotenoids, which can contribute significantly to the aroma of wines (GonzálezBarreiro et al., 2015), adding, in many cases, floral and fruity pleasant notes. In this context, the results in this study (Table 6) indicate that moderate level of 
iron deficiency chlorosis could improve the aromatic potential of grapes. Recently, Vannozzi et al. (2017) reported that grapevines grown with a limiting supply of iron increased the induction of the gen related to the biosynthesis of $\beta$-carotene hydroxylase (BCH1), an enzyme implicated in the carotenoid catabolic pathways. This enzyme is responsible for $\beta$-ring hydroxylation of $\beta$-carotene yielding zeaxanthin and $\beta$-cryptoxanthin, which are precursors of $\mathrm{C}_{13}$-norisoprenoids (Young et al., 2012). The overexpression of $\beta$-carotene hydroxylase under iron stress conditions was also coupled to the induction of certain genes related to the biosynthesis of terpenoids, which are important constituents of grape flavor (Vannozzi et al., 2017).

In addition to the direct effects mentioned above, iron deficiency could affect indirectly the synthesis of $\mathrm{C}_{13}$-norisoprenoids through the microclimate. In green berries, light appears to increase the concentration of carotenoids, which are photoprotective compounds considered to be precursors of $\mathrm{C}_{13}$-norisoprenoids (Bureau et al., 2000). Asproudi et al. (2016) suggested that a greater cluster exposure to sunlight in less vigorous plants favors norisoprenoids peak concentration during ripening while, on the other hand, very high temperature in the fruits would lead to a decline of total norisoprenoids content during the pre-harvest period. Moreno et al. (2017) investigated the effect of cluster exposure by early defoliation on volatile composition of Tempranillo wines during three consecutive harvests. These authors reported that defoliation increased the concentration of all families of volatile compound quantified, with exception of lactones, improving the fruity and floral aroma. In this study, it seems that direct effects of iron deficiency on biosynthesis of grape aroma compounds were greater than those produced through the microclimate, since there were no differences in vigor between high and low Chl subzones (Table 3).

Iron chlorosis was associated to higher concentrations of some volatile phenols, such as eugenol and 3,4-dimethoxyphenol in 2017 (Table 6). Bavaresco et al. (2005) suggested that, as iron is a constituent of enzymes involved in lignin synthesis, iron deficiency may switch the shikimate pathway towards other phenolics. The exposure of clusters to sunlight also would favor the accumulation of bound volatile phenols in grapes (González-Barreiro et al., 2015), although this effect seems to be negligible in the present study, as commented above for $\mathrm{C}_{13}$-norisoprenoids.

When the relationships between volatile aroma compounds with petiole nutrient content at veraison were examined, strong correlations between $\mathrm{N}$ with total free $\mathrm{C}_{6}$-alcohols were detected in $2016(\mathrm{r}=0.72$, $p<0.001)$ and $2017(\mathrm{r}=0.53, p<0.01)$. Regardless of the incidence of iron chlorosis, these results show that increasing levels of $\mathrm{N}$ assimilation in plants have a negative effect on the aromatic composition of grapes. The herbaceous aroma content could be increased due to an excess vigor (Song et al., 2012), which delays ripening.
It has been reported that nitrogen fertilization increased $\mathrm{C}_{6}$-alcohols concentrations in Pinot noir berries (Yuan et al., 2018) and Riesling wines (Webster et al., 1993), and promoted green aroma notes in Merlot wines (MendezCostabel et al., 2014). 4-Ethylphenol concentration in must was directly correlated with petiole Mg content $(\mathrm{r}$ $=0.65, p<0.01)$ in 2016, indicating that this smoky type of aroma tended to be more abundant in chlorotic than in non-chlorotic vines.

The relationships between concentrations of C6-alcohols, C13-norisoprenoids and volatile phenols with foliar chlorophyll level (Table 6) demonstrate that $\mathrm{Chl}$, as a symptom of iron deficiency and for its relationship with nitrogen status, could be useful as an early indicator of aromatic potential of grapes at harvest. Within rainfed vineyards moderately affected by iron chlorosis, the estimation of $\mathrm{Chl}$ at veraison using remote sensing technologies (Zarco-Tejada et al., 2004; Martín et al., 2007) allows delimiting subzones with higher (low-Chl) and lower (high-Chl) aroma quality potential. Grapes from different quality subzones could then be batched for separate winemaking.

\section{Aromas and maturity indices}

Table 7 shows that concentrations of free and total aroma compounds, free alcohols and free, and bound aldehydes detected in the must were directly correlated with vine yield, and non-correlated with berry size or technological maturity (TSS) in the first season. In the second one, spring frosts and water deficit in summer caused a general restriction in yield of vineyard subzones, and the Pearson coefficients between aroma contents and yield were not significant. Nevertheless, in 2017, free aldehydes and several groups of bound volatile compounds were directly correlated to TSS, while free and bound $\mathrm{C}_{6}$-alcohols concentrations were correlated to berry weight. Low water availability reduced vine vigor in 2017 (Table 3) thus tending to advance fruit ripening and reducing $\mathrm{C}_{6}$-alcohols concentrations.

Our results agree with those of Maoz et al. (2018), who reported variations on volatile analysis of Crimson Seedless table grapes based on acidity or TSS levels, but not according to berry weight. Although many studies have detected high correlation between volatiles and sugar concentrations in grapes (Coelho et al., 2007; Ubeda et al., 2017), others (Maoz et al., 2018) have reported that some specific volatile compounds increased with maturity grade and some others reported a decrease of volatile compounds. It is generally recognized that grape maturity affects the flavor profile parallel to the sugar content; however, it is well accepted that aromatic maturity is achieved before technological maturity (Marais, 1983).

The phenolic maturity, estimated as TPC, was related to the aroma potential of grapes both in 2016 and 2017 (Table 7). Total phenolic compounds were positively correlated to free terpenes, bound volatile acids, and bound volatile phenols concentrations, and negatively to free $\mathrm{C}_{6}$-alcohols in 2016. Bound alcohols and free and 
Table 7 - Pearson correlation coefficients between concentrations of must aroma compounds with vine yield, 100 berry weight (BW), total soluble solids (TSS) and total phenolic compound content (TPC) in the grapes.

\begin{tabular}{|c|c|c|c|c|c|c|}
\hline \multirow[t]{2}{*}{ Year } & \multicolumn{2}{|r|}{ Type / group } & Yield & \multirow{2}{*}{$\begin{array}{r}\text { BW } \\
*-0.01\end{array}$} & \multirow{2}{*}{$\begin{array}{r}\text { TSS } \\
-0.40\end{array}$} & \multirow{2}{*}{$\begin{array}{r}\text { TPC } \\
-0.32\end{array}$} \\
\hline & \multirow{10}{*}{$\begin{array}{l}\text { Free } \\
\text { aromas }\end{array}$} & Alcohols & & & & \\
\hline \multirow{20}{*}{2016} & & $\mathrm{C}_{6}$-Alcohols & 0.08 & 0.13 & -0.02 & $-0.58^{* *}$ \\
\hline & & Aldehydes & $0.44^{*}$ & -0.01 & -0.41 & 0.13 \\
\hline & & Terpenes & 0.03 & -0.11 & 0.04 & $0.68^{* * *}$ \\
\hline & & Volatile acids & 0.00 & 0.23 & 0.41 & -0.10 \\
\hline & & $\mathrm{C}_{13}$-Norisoprenoids & s 0.05 & 0.33 & 0.36 & -0.10 \\
\hline & & Volatile phenols & 0.05 & 0.15 & 0.27 & 0.05 \\
\hline & & Acetates & 0.04 & 0.02 & 0.11 & -0.12 \\
\hline & & Lactones & -0.04 & 0.41 & 0.32 & -0.26 \\
\hline & & Total free & $0.44^{*}$ & 0.26 & -0.19 & -0.29 \\
\hline & \multirow{10}{*}{$\begin{array}{l}\text { Bound } \\
\text { aromas }\end{array}$} & Alcohols & 0.32 & 0.02 & -0.11 & 0.03 \\
\hline & & $\mathrm{C}_{6}$-Alcohols & 0.38 & 0.19 & 0.18 & 0.26 \\
\hline & & Aldehydes & $0.61^{\text {* * }}$ & * 0.27 & -0.32 & 0.01 \\
\hline & & Terpenes & 0.27 & 0.21 & 0.07 & -0.01 \\
\hline & & Volatile acids & 0.36 & 0.03 & 0.25 & $0.58^{* *}$ \\
\hline & & $\mathrm{C}_{13}$-Norisoprenoids & $s-0.09$ & 0.10 & 0.01 & -0.29 \\
\hline & & Volatile phenols & 0.04 & -0.07 & 0.28 & $0.44^{*}$ \\
\hline & & Acetates & 0.34 & -0.05 & -0.31 & -0.28 \\
\hline & & Lactones & -0.14 & 0.10 & 0.41 & -0.07 \\
\hline & & Total bound & 0.25 & 0.13 & 0.26 & 0.18 \\
\hline & \multicolumn{2}{|c|}{ Total aromas } & $0.47^{\star}$ & 0.26 & 0.10 & -0.03 \\
\hline \multirow{24}{*}{2017} & \multirow{12}{*}{$\begin{array}{l}\text { Free } \\
\text { aromas }\end{array}$} & Alcohols & -0.24 & 0.26 & $0.46^{*}$ & 0.02 \\
\hline & & $\mathrm{C}_{6}$-Alcohols & -0.14 & $0.53^{*}$ & * 0.04 & -0.15 \\
\hline & & Aldehydes & -0.08 & 0.17 & $0.53^{*}$ & 0.19 \\
\hline & & Terpenes & -0.21 & 0.17 & 0.34 & 0.02 \\
\hline & & $\begin{array}{l}\text { Carbonyl } \\
\text { compounds }\end{array}$ & 0.32 & -0.25 & -0.28 & 0.11 \\
\hline & & Volatile acids & -0.23 & -0.23 & 0.19 & $0.48^{*}$ \\
\hline & & $\mathrm{C}_{13}$-Norisoprenoids & $s-0.16$ & -0.12 & 0.27 & 0.16 \\
\hline & & Volatile phenols & -0.21 & 0.12 & 0.24 & 0.06 \\
\hline & & Acetates & -0.21 & 0.24 & 0.28 & 0.10 \\
\hline & & Ethyl esters & 0.10 & -0.22 & -0.13 & 0.21 \\
\hline & & Lactones & -0.23 & 0.20 & 0.31 & 0.00 \\
\hline & & Total free & -0.22 & 0.43 & 0.09 & -0.01 \\
\hline & \multirow{11}{*}{$\begin{array}{l}\text { Bound } \\
\text { aromas }\end{array}$} & Alcohols & -0.08 & 0.35 & 0.34 & $0.50^{*}$ \\
\hline & & $\mathrm{C}_{6}$-Alcohols & 0.13 & $0.55^{*}$ & * -0.10 & 0.14 \\
\hline & & Aldehydes & -0.03 & -0.01 & -0.22 & 0.06 \\
\hline & & Terpenes & -0.17 & 0.28 & $0.53^{*}$ & 0.31 \\
\hline & & Volatile acids & -0.28 & 0.06 & $0.54^{*}$ & $0.53^{*}$ \\
\hline & & $\mathrm{C}_{13}$-Norisoprenoids & $s-0.09$ & 0.33 & 0.32 & 0.28 \\
\hline & & Volatile phenols & -0.17 & 0.32 & $0.45^{*}$ & 0.34 \\
\hline & & Acetates & -0.16 & 0.18 & $0.51^{*}$ & 0.11 \\
\hline & & Lactones & -0.21 & 0.25 & $0.58^{* *}$ & * 0.35 \\
\hline & & Ethyl esters & -0.18 & 0.16 & $0.58^{* *}$ & * 0.22 \\
\hline & & Total bound & -0.20 & 0.29 & $0.57^{* *}$ & * 0.37 \\
\hline & \multicolumn{2}{|c|}{ Total aromas } & -0.30 & $0.47^{*}$ & * 0.35 & 0.23 \\
\hline
\end{tabular}

* Significant $p<0.05 ;{ }^{* *}$ Significant $p<0.01 ;{ }^{* * *}$ Significant $p<0.001$.

bound volatile acids were positively correlated to TPC in 2017. Grapes that are phenolically ripe contain higher amounts of pleasant aromatic compounds and lower levels of green herbaceous and vegetable compounds, such as $\mathrm{C}_{6}$-alcohols (Hellín et al., 2010).

\section{Conclusions}

Our results show that grapes from more water or iron stressed vines restricted $\mathrm{C}_{6}$-alcohols concentrations and reached more favorable aromatic maturity levels than non-stressed grapes. Our results demonstrate that mild to moderate iron deficiency can have positive effects on grape aromatic quality through the increase of biosynthesis of $\mathrm{C}_{13}$-norisoprenoids and volatile phenols, irrespective of its impact on vegetative growth, yield or berry size. Foliar chlorophyll content, measured at veraison, could be a useful tool in precision viticulture to early characterization of the grape aromatic potential within rainfed vineyards affected by iron deficiency.

\section{Acknowledgements}

This research was supported by RTA201400077-C02-02 (from INIA and the Spanish Ministry of Economy and Competitiveness) and VA013P17 (Junta de Castilla y León) projects, and co-financed with FEDER Funds. The authors are grateful to Bodegas Emilio Moro S.L. for their collaboration to conduct this research.

\section{Authors' Contributions}

Conceptualization: González, M.R.; Vilanova, M.; Martín, P. Data acquisition: Sánchez, R.; González, M.R.; Vilanova, M.; Rodríguez-Nogales, J.M. Data analysis: González, M.R.; Martín, P. Design of methodology: González, M.R.; Vilanova, M.; RodríguezNogales, J.M.; Martín, P. Writing and editing: Sánchez, R.; González, M.R.; Vilanova, M.; Rodríguez-Nogales, J.M.; Martín, P.

\section{References}

Agarwala, S.C.; Mehrotra, S.C. 1984. Iron-magnesium antagonism in growth and metabolism of radish. Plant and Soil 80: 355-361. Asproudi, A.; Petrozziello, M.; Cavalletto, S.; Guidoni, S. 2016. Grape aroma precursors in cv. Nebbiolo as affected by vine microclimate. Food Chemistry 211: 947-956.

Balint, G.; Reynolds, A.G. 2014. Effect of different irrigation strategies on vine physiology, yield, grape composition and sensory profiles of Vitis vinifera L. Cabernet Sauvignon in a cool climate area. Journal International des Sciences de la Vigne et du Vin 48: 269-292.

Balint, G.; Reynolds, A.G. 2017. Irrigation strategies impact Baco noir grapevines in Ontario. II. Fruit composition and wine sensory analysis. American Journal of Enology and Viticulture 68: 310-324.

Bavaresco, L.; Bertamini, M.; Iacono, F. 2006. Lime-induced chlorosis and physiological responses in grapevine (Vitis vinifera L. cv. Pinot blanc) leaves. Vitis 45: 45-46.

Bavaresco, L.; Civardi, S.; Pezzutto, S.; Vezzulli, S.; Ferrari, F. 2005. Grape production, technological parameters, and stilbenic compounds as affected by lime-induced chlorosis. Vitis 44: 63-65. 
Bavaresco, L.; Giachino, E.; Colla, R. 1999. Iron chlorosis paradox in grapevine. Journal of Plant Nutrition 22: 1589-1597.

Boulton, R. 1980. The general relationship between potassium, sodium and $\mathrm{pH}$ in grape juice and wine. American Journal of Enology and Viticulture 31: 182-186.

Bureau, S.M.; Baumes, R.L.; Razungles, A.J. 2000. Effects of vine or bunch shading on the glycosylated flavor precursors in grapes of Vitis vinifera L. cv. Syrah. Journal of Agricultural and Food Chemistry 48: 1290-1297.

Chapman, D.M.; Roby, G.; Ebeler, S.E.; Guinard, J.X.; Matthews, M.A. 2005. Sensory attributes of Cabernet Sauvignon wines made from vines with different water status. Australian Journal of Grape and Wine Research 11: 339-347.

Coelho, E.; Coimbra, M.A.; Nogueira, J.M.F.; Rocha, S.M. 2009. Quantification approach for assessment of sparkling wine volatiles from different soils, ripening stages, and varieties by stir bar sorptive extraction with liquid desorption. Analytica Chimica Acta 635: 214-221.

Coelho, E.; Rocha, S.M.; Barros, A.S.; Delgadillo, I.; Coimbra, M.A. 2007. Screening of variety- and pre-fermentation-related volatile compounds during ripening of white grapes to define their evolution profile. Analytica Chimica Acta 597: 257-264.

Echeverría, G.; Ferrer, M.; Mirás-Avalos, J.M. 2017. Effects of soil type on vineyard performance and berry composition in the Río de la Plata coast (Uruguay). OENO One 51: 251-261.

European Commission. 1990. Regulation (EEC) $N^{\circ}$ 2676/90 of 17 Sept 1990. Community methods for the analysis of wines. Official Journal of the European Communities L272 (3/10/1990): 0001-0192.

Flexas, J.; Bota, J.; Escalona, J.M.; Sampol, B.; Medrano, H. 2002. Effects of drought on photosynthesis in grapevines under field conditions: an evaluation of stomatal and mesophyll limitations. Functional Plant Biology 29: 461-471.

Gamero, E.; Moreno, D.; Vilanova, M.; Uriarte, D.; Prieto, M.H.; Valdés, M.E. 2014. Effect of bunch thinning and water stress on chemical and sensory characteristics of Tempranillo wines. Australian Journal of Grape and Wine Research 20: 394-400.

González-Barreiro, C.; Rial-Otero, R.; Cancho-Grande, B.; SimalGándara, J. 2015. Wine aroma compounds in grapes: a critical review. Critical Reviews in Food Science and Nutrition 55: 202-218.

González, M.R.; Hailemichael, G.; Catalina, A.; Martín, P. 2019. Combined effects of water status and iron deficiency chlorosis on grape composition within non-irrigated vineyards. Scientia Agricola 76: 473-480.

Hailemichael, G.; Catalina, A.; González, M.R.; Martín, P. 2016. Relationships between water status, leaf chlorophyll content and photosynthetic performance in Tempranillo vineyards. South African Journal of Enology and Viticulture 37: 149-156.

Hellín, P.; Manso, A.; Flores, P.; Fenoll, J. 2010. Evolution of aroma and phenolic compounds during ripening of 'Superior seedless' grapes. Journal of Agricultural and Food Chemistry 58: 6334-6340.

International Organisation of Vine and Wine [OIV]. 1996. Foliar diagnosis a harmonized method = Résolution VITI 4/95. Diagnostic foliare une méthode harmonisée. Bulletin de l'OIV 69: 779-780 (in French).
Ledderhof, D.; Reynolds, A.G.; Manin, L.; Brown, R. 2014. Influence of water status on sensory profiles of Ontario Pinot noir wines. LWT - Food Science and Technology 57: 65-82.

Li, T.; Hao, X.M.; Kang, S.Z.; Leng, D. 2017. Spatial variation of winegrape yield and berry composition and their relationships with spatiotemporal distribution of soil water content. American Journal of Enology and Viticulture 68: 369-377.

López, R.; Ezpeleta, E.; Sánchez, I.; Cacho, J.; Ferreira, V. 2004. Analysis of the aroma intensities of volatile compounds released from mild acid hydrolysates of odourless precursors extracted from Tempranillo and Grenache grapes using gas chromatography-olfactometry. Food Chemistry 88: 95-103.

Maoz, I.; Kaplunov, T.; Beno-Mualem, S.; Lewinsohn, E.; Lichter, A. 2018. Variability in volatile composition of Crimson seedless (Vitis vinifera) in association to maturity at harvest. American Journal of Enology and Viticulture 69: 125-132.

Marais, J. 1983. Terpenes in the aroma of grapes and wines: a review. South African Journal of Enology and Viticulture 4: 49-60.

Martín, P.; Zarco-Tejada, P.J.; González, M.R.; Berjón, A. 2007. Using hyperspectral remote sensing to map grape quality in 'Tempranillo' vineyards affected by iron chlorosis. Vitis 46: 7-14.

Martín, P.; Zarco-Tejada, P.J.; González, M.R. 2008. Nutritional diagnosis and fertilizer recommendations in the limestone soils of Ribera de Duero = Diagnostico nutricional $y$ recomendaciones de abonado en suelos calizos de la Ribera de Duero. Vida Rural 270: 26-32 (in Spanish).

Mendez-Costabel, M.P.; Wilkinson, K.L.; Bastian, S.E.P.; Jordans, C.; McCarthy, M.; Ford, C.M.; Dokoozlian, N.K. 2014. Effect of increased irrigation and additional nitrogen fertilisation on the concentration of green aroma compounds in Vitis vinifera L. Merlot fruit and wine. Australian Journal of Grape and Wine Research 20: 80-90.

Millaleo, R.; Reyes-Díaz, M.; Ivanov, A.G.; Mora, M.L.; Alberdi, M. 2010. Manganese as essential and toxic element for plants: transport, accumulation and resistance mechanisms. Journal of Soil Science and Plant Nutrition 10: 470-481.

Morales, F.; Grasa, R.; Abadía, A.; Abadía, J. 1998. Iron chlorosis paradox in fruit trees. Journal of Plant Nutrition 21: 815-825.

Moreno, D.; Valdés, E.; Uriarte, D.; Gamero, E.; Talaverano, I.; Vilanova, M. 2017. Early leaf removal applied in warm climatic conditions: impact on Tempranillo wine volatiles. Food Research International 98: 50-58.

Mozzon, M.; Savini, S.; Boselli, E.; Thorngate, J.H. 2016. The herbaceous character of wines. Italian Journal of Food Science 28: 190-207.

Ojeda, H.; Andara, C.; Kraeva, E.; Carbonneau, A.; Deloire, A. 2002. Influence of pre- and postveraison water deficit on synthesis and concentration of skin phenolic compounds during berry growth of Vitis vinifera cv. Syrah. American Journal of Enology and Viticulture 53: 261-267.

Oliveira, J.M.; Oliveira, P.; Baumes, R.L.; Maia, M.O. 2008. Volatile and glycosidically bound composition of Loureiro and Alvarinho wines. Food Science and Technology International 14: 341-353.

Pirie, A.J.G.; Mullins, M.G. 1980. Concentration of phenolics in skin of grape berries during fruit development and ripening. American Journal of Enology and Viticulture 31: 34-36. 
Podolyan, A.; White, J.; Jordan, B.; Winefield, C. 2010. Identification of the lipoxygenase gene family from Vitis vinifera and biochemical characterisation of two 13-lipoxygenases expressed in grape berries of Sauvignon Blanc. Functional Plant Biology 37: 767-784.

Reynolds, A.G.; Sorokowsky, D.; Gensler, W. 2012. Evapotranspiration-based irrigation scheduling for Syrah: assessing vine water status by petiole electrical potential. American Journal of Enology and Viticulture 63: 343-356.

Robinson, A.L.; Boss, P.K.; Solomon, P.S.; Trengove, R.D.; Heymann, H.; Ebeler, S.E. 2014. Origins of grape and wine aroma. Part 1. Chemical components and viticultural impacts. American Journal of Enology and Viticulture 65: 1-24.

Romero, P.; Fernández-Fernández, J.I.; Martinez-Cutillas, A. 2010. Physiological thresholds for efficient regulated deficitirrigation management in winegrapes grown under semiarid conditions. American Journal of Enology and Viticulture 61: 300-312.

Saint-Cricq, N.; Vivas, N.; Glories, Y. 1998. Phenolic maturation of red grapes. Relationship with the quality of the wines. Comparison of Merlot and Tempranillo grape varieties. = Maturation phénolique des raisins rouges. Relation avec la qualité des vins. Comparaison des cépages Merlot et Tempranillo. Le Progrés Agricole et Viticole 115: 306-318 (in French).

Salinas, M.R.; Zalacain, A.; Pardo, F.; Alonso, G.L. 2004. Stir bar sorptive extraction applied to volatile constituents evolution during Vitis vinifera ripening. Journal of Agricultural and Food Chemistry 52: 4821-4827.

Santesteban, L.G.; Miranda, C.; Royo, J.B. 2011. Suitability of pre-dawn and stem water potential as indicators of vineyard water status in cv. Tempranillo. Australian Journal of Grape and Wine Research 17: 43-51.

Song, J.; Shellie, K.C.; Wang, H.; Qian, M.C. 2012. Influence of deficit irrigation and kaolin particle film on grape composition and volatile compounds in Merlot grape (Vitis vinifera L.). Food Chemistry 134: 841-850.

Tagliavini, M.; Rombolà, A.D. 2001. Iron deficiency and chlorosis in orchard and vineyard ecosystems. European Journal of Agronomy 15: 71-92.

Talaverano, M.I.; Valdés, E.; Moreno, D.; Gamero, E.; Mancha, L.M.; Vilanova, M. 2017. The combined effect of water status and cluster thinning on Tempranillo wine volatiles. Journal of the Science of Food and Agriculture 99: 1533-1542.

Ubeda, C.; Cortiella, M.G.; Del Barrio, R.; Peña-Neira, A. 2017. Influence of maturity and vineyard location on free and bound aroma compounds of grapes from the País cultivar. South African Journal of Enology and Viticulture 38: 201-211.
Val, J.; Monge, E.; Heras, L.; Abadía, J. 1987. Changes in photosynthetic pigment composition in higher plants as affected by iron nutrition status. Journal of Plant Nutrition 10: 995-1001.

Van-Leeuwen, C.; Tregoat, O.; Choné, X.; Bois, B.; Pernet, D.; Gaudillère, J.P. 2009. Vine water status is a key factor in grape ripening and vintage quality for red Bordeaux wine: how can it be assessed for vineyard management purposes? Journal International des Sciences de la Vigne et du Vin 43: 121-134.

Vannozzi, A.; Donnini, S.; Vigani G.; Corso, M.; Valle, G.; Vitulo, N.; Bonghi, C.; Zocchi, G.; Lucchin, M. 2017. Transcriptional characterization of a widely-used grapevine rootstock genotype under different iron-limited conditions. Frontiers in Plant Science 7: 1-17.

Vilanova, M.; Genisheva, T.; Tubio, M.; Alvarez, K.; Lissarrague, J.R.; Oliveira, J.M. 2017. Effect of Vertical Shoot-Positioned, Scott-Henry, Geneva Double-Curtain, Arch-cane and Parral training systems on volatile composition of Albariño wines. Molecules 22: 1-13.

Vilanova, M.; Rodríguez-Nogales, J.M.; Vila-Crespo, J.; Yuste, J. 2019. Influence of water regime on yield components, must chemicals and wine volatiles of cv. Verdejo. Australian Journal of Grape and Wine Research 25: 83-91.

Vilanova, M.; Zamuz, S.; Vilariño, F.; Sieiro, C. 2007. Effect of terroir on the volatiles of Vitis vinifera cv. Albariño. Journal of Science of Food and Agriculture 87: 1252-1256.

Webster, D.R.; Edwards, C.G.; Spayd, S.E.; Peterson, J.C.; Seymour, B.J. 1993. Influence of vineyard nitrogen fertilization on the concentrations of monoterpenes, higher alcohols, and esters in aged Riesling wines. American Journal of Enology and Viticulture 44: 275-284.

Young, P.R.; Lashbrooke, J.G.; Alexandersson, E.; Jacobson, D.; Moser, C.; Velasco, R.; Vivier, M.A. 2012. The genes and enzymes of the carotenoid metabolic pathway in Vitis vinifera L. BMC Genomics 13: 1-17.

Yuan, F.; Schreiner, R.P.; Qian, M.C. 2018. Soil nitrogen, phosphorus, and potassium alter $\beta$-damascenone and other volatiles in Pinot Noir berries. American Journal of Enology and Viticulture 69: 157-166.

Zarco-Tejada, P.J.; Catalina, A.; González, M.R.; Martín, P. 2013. Relationships between net photosynthesis and steady-state chlorophyll fluorescence retrieved from airborne hyperspectral imagery. Remote Sensing of Environment 136: 247-258.

Zarco-Tejada, P.J.; Miller, J.R.; Morales, A.; Berjón, A.; Agüera, J. 2004. Hyperspectral indices and model simulation for chlorophyll estimation in open-canopy tree crops. Remote Sensing of Environment 90: 463-476. 